\title{
Recognition of two genetic groups in the Klebsiella oxytoca taxon on the basis of chromosomal $\beta$-lactamase and housekeeping gene sequences as well as ERIC-1R PCR typing
}

\author{
Sophie A. Granier, ${ }^{1,2}$ Laetitia Plaisance, ${ }^{3}$ Véronique Leflon-Guibout, ${ }^{1}$ \\ Evelyne Lagier, ${ }^{4}$ Serge Morand, ${ }^{3}$ Fred W. Goldstein ${ }^{2}$ \\ and Marie-Hélène Nicolas-Chanoine ${ }^{1}$ \\ ${ }^{1}$ Service de Microbiologie-Hygiène, Hôpital Ambroise Paré AP-HP, Université Versailles-Saint- \\ Quentin-en-Yvelines-UFR Médicale Paris-Ile-de-France-Ouest, 9 avenue Charles de Gaulle, \\ 92100 Boulogne-Billancourt, France \\ ${ }^{2}$ Laboratoire de Microbiologie Médicale, Fondation Hôpital Saint-Joseph, Paris, France \\ ${ }^{3}$ Centre de Biologie et d'Ecologie Tropicale et Méditerranéenne, UMR 5555, Université de \\ Perpignan, France \\ ${ }^{4}$ Service de Microbiologie, Centre Hospitalier du Pays d'Aix, Aix en Provence, France
}

Correspondence

Marie-Hélène Nicolas-Chanoine marie-helene.nicolas-chanoine@ apr.ap-hop-paris.fr

\section{INTRODUCTION}

Klebsiella oxytoca is an opportunistic pathogen that has been involved in various nosocomial infections (Boyeldieu et al., 1999; Jeong et al., 2001; Reiss et al., 2000) and also in antibiotic-associated diarrhoea (Benoit et al., 1992; Högenauer et al., 1998; Terrier et al., 1995).

Methods routinely used for species identification are not able to differentiate $K$. oxytoca from the other indole-positive

Published online ahead of print on 23 August 2002 as DOI 10.1099/ijs.0.02408-0.

Abbreviations: ERIC, enterobacterial repetitive intergenic consensus; RAPD, randomly amplified polymorphic DNA.

Alignments of consensus DNA sequences of the $16 \mathrm{~S}$ rRNA and and rpoB genes are available as supplementary data in IJSEM Online. 
Klebsiella species: Klebsiella ornithinolytica, Klebsiella planticola and Klebsiella terrigena (Monnet et al., 1991). However, recent molecular studies have definitively demonstrated that K. oxytoca is phylogenetically distant from the other indole-positive Klebsiella species, on the basis of $16 \mathrm{~S}$ rRNA and $r p o B$ gene sequence analysis (Drancourt et al., 2001). For this reason, the indole-positive Klebsiella species other than $K$. oxytoca have recently been renamed as Raoultella species (Drancourt et al., 2001).

Both K. oxytoca and Raoultella species are naturally resistant to amino- and carboxypenicillins, but are susceptible to the amoxicillin-clavulanate combination (Stock \& Wiedemann, 2001). Until now, the chromosomal $\beta$-lactamase responsible for this $\beta$-lactam-resistance phenotype has been defined only for $K$. oxytoca, and was shown to belong to class A of the $\beta$-lactamases. Although its production is not regulated, up-mutations induce its overproduction, resulting in the resistance of isolates to certain third-generation cephalosporins (ceftriaxone and cefotaxime) and aztreonam (Fournier et al., 1994).

Fournier et al. (1996b) have determined two groups of chromosomal $\beta$-lactamase in K. oxytoca, OXY- 1 and OXY-2, with isoelectric points ranging from $7 \cdot 1$ to $8 \cdot 8$ and $5 \cdot 2$ to $6 \cdot 8$, respectively. The corresponding genes, $b l a_{\mathrm{OXY}-1}$ and $b l a_{\mathrm{OXY}-2}$, display a nucleotide sequence identity of $87 \%$. Whilst searching for a molecular method to identify the different species of Raoultella and K. oxytoca, we observed that the OXY-1 $\beta$-lactamase-producing and the OXY-2 $\beta$-lactamase-producing isolates displayed two distinct profiles generated by the enterobacterial repetitive intergenic consensus (ERIC)-1R PCR typing system, and that each profile had characteristic bands. Faced with such a result, we hypothesized that the two groups of $\beta$-lactamases (OXY-1 and OXY-2) of K. oxytoca might correspond to two groups of strains in the K. oxytoca taxon. We confirmed this hypothesis by studying the sequence of the $b l a_{\mathrm{OXY}}, 16 \mathrm{~S}$ rRNA and $r p o B$ genes in epidemiologically non-related clinical isolates of $K$. oxytoca and reference strains.

To our knowledge, this study is the first to show that chromosomal $\beta$-lactamase genes are able to identify clades within a given species, as do housekeeping genes such as $16 \mathrm{~S}$ rDNA and $r p o B$.

\section{METHODS}

Strains. Thirteen non-redundant clinical isolates of $K$. oxytoca were studied in comparison with reference strains SL781 (=CIP 104963) and SL911 ( = CIP 106098), producing OXY-1 and OXY-2 $\beta$-lactamases, respectively. Those clinical isolates $(n=10$ : SG12, SG49, SG337, SG344, SG43, SG69, SG77, SG9, SG4 and SG62) that displayed an extended spectrum of resistance to certain $\beta$-lactam molecules (ceftriaxone, cefotaxime and aztreonam) had been collected between 1984 and 1998, in six French hospitals representing the northern and southern regions of France and the Paris area. The three remaining isolates (SG74, SG81 and SG176) were susceptible to third-generation cephalosporins and aztreonam, and were obtained from three patients hospitalized in the Saint Joseph hospital in 1999 and 2000 .

Mating-out assays and plasmid content analysis. Transfer of $\beta$-lactam resistance to Escherichia coli $\mathrm{K}-12 \mathrm{C} 600 \mathrm{~S} 1000\left(\mathrm{Str}^{\mathrm{R}}\right)$ was attempted by liquid and solid mating-out assays. The recipient and donor cells were mixed in a ratio of $1: 1$ and incubated in broth with moderate shaking at $37^{\circ} \mathrm{C}$ for $1 \mathrm{~h}$. Five hundred microlitres of each mixture was plated out on tryptic soy agar (TSA) plates and incubated overnight at $37^{\circ} \mathrm{C}$. Transconjugants were selected on Drigalski agar containing ampicillin $\left(20 \mathrm{mg} \mathrm{l}^{-1}\right)$ and streptomycin $\left(100 \mathrm{mg} \mathrm{l}^{-1}\right)$. Clinical isolates of $K$. oxytoca were examined for their plasmid DNA content by the procedure of Birnboim (1983).

DNA preparation. DNA templates were prepared by suspending a freshly grown colony in $500 \mu \mathrm{l}$ lysis buffer $(20 \mathrm{mM}$ Tris/ $\mathrm{HCl}$ $\mathrm{pH} 8 \cdot 3,50 \mathrm{mM} \mathrm{KCl}, 0 \cdot 1 \%$ Tween 20 ) and heating at $94{ }^{\circ} \mathrm{C}$ for $10 \mathrm{~min}$. DNA preparations were stored at $-20^{\circ} \mathrm{C}$.

Gene amplification and sequencing. To amplify the promoter and the coding regions of the $b l a_{\mathrm{OXY}}$ genes, two primers were designed, one upstream from the promoter region (OXY-A: $5^{\prime}$ TCGGTAACTGTGACGGGA-3') and one downstream from the coding region (OXY-B: $5^{\prime}$-CCGAATTTCGGGAAGCCA-3'), on the basis of the $b a_{\mathrm{OXY}}$ sequences published previously. These primers generate a fragment of $1040 \mathrm{bp}$. The PCR mixture contained $20 \mathrm{mM}$ Tris/ $\mathrm{HCl} \mathrm{pH} 8.0,100 \mathrm{mM} \mathrm{KCl}, 1.5 \mathrm{mM} \mathrm{MgCl}_{2}, 500 \mu \mathrm{M}$ each dNTP, $0 \cdot 2 \mu \mathrm{M}$ each primer and $0.0025 \mathrm{U}$ Taq DNA polymerase $\mu 1^{-1}$. The amplification reaction consisted of a pre-PCR stage (at $94{ }^{\circ} \mathrm{C}$ for $5 \mathrm{~min}$, at $51^{\circ} \mathrm{C}$ for $1 \mathrm{~min}$ and at $72^{\circ} \mathrm{C}$ for $1 \mathrm{~min}$ ), and then 45 cycles at $94{ }^{\circ} \mathrm{C}$ for $30 \mathrm{~s}$, at $51^{\circ} \mathrm{C}$ for $30 \mathrm{~s}$ and at $72{ }^{\circ} \mathrm{C}$ for $30 \mathrm{~s}$, and a final extension step at $72{ }^{\circ} \mathrm{C}$ for $10 \mathrm{~min}$.

$16 \mathrm{~S}$ rDNA was amplified with two primers complementary to highly conserved regions in Gram-negative rRNA (A12, 5' AAGCCTGATGCAGCCA-3'; A13, 5' -TTTCGCACCTGAGCGT-3'). The amplified fragment, which displays a great nucleotide variability in Gram-negative bacteria, starts at position 381 and ends at position 767 (387 bp) relative to the E. coli $16 \mathrm{~S}$ rDNA sequence. The PCR mixture was identical to that described above, except for the $\mathrm{MgCl}_{2}$ concentration, which was higher $(2.5 \mathrm{mM})$. The reaction was performed with a pre-denaturation step for $5 \mathrm{~min}$ at $95^{\circ} \mathrm{C}$, then 35 cycles for $1 \mathrm{~min}$ at $95^{\circ} \mathrm{C}$, for $1 \mathrm{~min}$ at $45^{\circ} \mathrm{C}$ and for $1 \mathrm{~min}$ at $72^{\circ} \mathrm{C}$, followed by a final extension step at $72{ }^{\circ} \mathrm{C}$ for $10 \mathrm{~min}$.

The $r p o B$ gene was partially amplified (512 bp) by using the primers $\mathrm{CM} 32 \mathrm{~B}$ and $\mathrm{CM} 81 \mathrm{~B}$, together with the conditions described by Mollet et al. (1997). The first nucleotide of the fragment studied corresponds to codon 500 of the 1342 aa coding region in E. coli.

PCR products were sequenced by using an automated cycle sequencing system, with the same primers as for the PCR. However, for the $b l a_{\mathrm{OXY}}$ gene, two additional internal primers were selected, OXY-C $\left(5^{\prime}\right.$ TATTAAAACAGAG-3') and OXY-D (5'-ATTAGAGGTCGGAA-3'), to obtain two additional priming sites for sequencing.

Sequence data analysis. Single sequence alignments were performed by using BLAST 2 sequence software (Tatusova \& Madden, 1999), whereas multiple sequence alignments were performed with DIALIGN 2 software (Morgenstern, 1999). The $b l a_{\text {OXY }}$ gene sequences of our isolates were compared with those of reference strains SL781 $\left(b l a_{\mathrm{OXY}-1}\right)$ and SL911 $\left(\right.$ bla $\left._{\mathrm{OXY}-2}\right)$ whose GenBank acession numbers are Z30177 and Z49084, respectively. The $r p o B$ and $16 \mathrm{~S}$ rDNA consensus sequences were constructed by using CAP software (Huang, 1992).

Tree reconstruction. Phylogenetic analyses were based on parsimony and were performed using version $4.0 \mathrm{~b} 5$ of PAUP* (Swofford, 1998). Separate analysis was performed for each of the rpoB and $16 \mathrm{~S}$ 
rDNA sequence datasets. Both datasets were then grouped in a combined analysis according to the total-evidence method (Huelsenbeck, 1996). The analysis used a branch-and-bound search on all equally weighted characters. Gaps were considered to be missing data. Branch support was estimated using bootstrap analysis (1000 replicates). We added four external taxa: E. coli ATCC $25922^{\mathrm{T}}$ (GenBank accession numbers for $r p o B$ and $16 \mathrm{~S}$ rDNA: U77436 and AF233451, respectively); Raoultella ornithinolytica ATCC $31898^{\mathrm{T}}$ (AF129447 and AF129441, respectively); Raoultella planticola ATCC $33531^{\mathrm{T}}$ (AF129449 and AF129443, respectively); and Klebsiella pneumoniae ATCC $13883^{\mathrm{T}}$ (U77444 and AF130981, respectively), to test the monophyly of the $K$. oxytoca strains. The tree was rooted using Rickettsia conorii ATCC VR-141 ${ }^{\mathrm{T}}$ (rpoB and 16S rDNA GenBank accession numbers are AF076435 and L36105, respectively) as the outgroup.

Arbitrarily amplified DNA polymorphism. The primer used was the Enterobacterial Repetitive Intergenic Consensus sequence corresponding to ERIC-1R: 5'-ATGTAAGCTCCTGGGGATTCAC-3' (Jones et al., 1999). Amplification was performed with the ReadyTo-Go RAPD Analysis Bead kit (Amersham Biosciences) under the conditions recommended by the manufacturer.

GenBank accession numbers. The sequences determined in this study have been submitted to GenBank and their corresponding accession numbers are presented in Table 1.

\section{RESULTS}

\section{Mating-out assays and plasmid content analysis}

A plasmid was detected in only two strains, SG81 and SG176. The transfer of these plasmids into E. coli resulted in transconjugants resistant to ampicillin. The gene encoding ampicillin resistance was not amplified with the primers specific for $b l a_{\mathrm{OXY}}$ genes, but with primers specific for $b l a_{\text {TEM }}$ genes as published previously (Granier et al., 2002b).

As the majority of $K$. oxytoca isolates were plasmid-free, and as repeated mating-out experiments failed to transfer $b l a_{\mathrm{OXY}}$ genes, these genes were assumed to be located on the bacterial chromosome.

\section{bla oxy gene sequences}

According to the nucleotide sequences of the $b a_{\mathrm{OXY}}$ genes of the 13 clinical isolates in comparison with those of reference strains SL781 and SL911, four isolates possessed a $b l a_{\mathrm{OXY}-1}$ gene and nine possessed a $b l a_{\mathrm{OXY}-2}$ gene (Tables 2 and 3). All the $b a_{\text {OXY-1 }}$ genes of clinical isolates differed from that of the reference strain SL781 by a single nucleotide substitution (G8A) in the promoter region. They also differed from each other and from the reference $b l a_{\mathrm{OXY}-1}$ gene within the coding region, either by point mutations leading to amino acid substitutions (Ala237Gly, Ala230Val), silent substitutions (G658A), or by a deletion of the first three or last three nucleotides of the palindromic sequence GCCG, starting at position 71. This resulted in the deletion of the Ala residue at position 12 according to the numbering of Ambler et al. (1991) (Table 2). Similar features were found in the $b l a_{\mathrm{OXY}-2}$ genes of clinical isolates with respect to reference strain SL911 (Table 3). Six of the nine $b l a_{\mathrm{OXY}-2}$ genes had substitutions in the promoter region, which consisted not only of G8A but also G12T. Five nucleotide substitutions located in the coding region led to amino acid substitutions (Gly20Ser, Asp35Ala, Asp197Asn, Asp255Asn and Val260Ile), whereas two were silent substitutions (A602G and C728A). The deletion of the Ala residue at position 12, which also occurred in the $b l a_{\mathrm{OXY}-2}$ gene, resulted from the deletion of the first three or the last three nucleotides of the palindromic sequence GCCG, starting at position 69.

Overall, a single $b l a_{\mathrm{OXY}}$ gene sequence was observed for the $b l a_{\mathrm{OXY}-1}$ genes harboured by our four clinical isolates, whereas five single $b a_{\mathrm{OXY}}$ gene sequences were observed for

Table 1. GenBank accession numbers

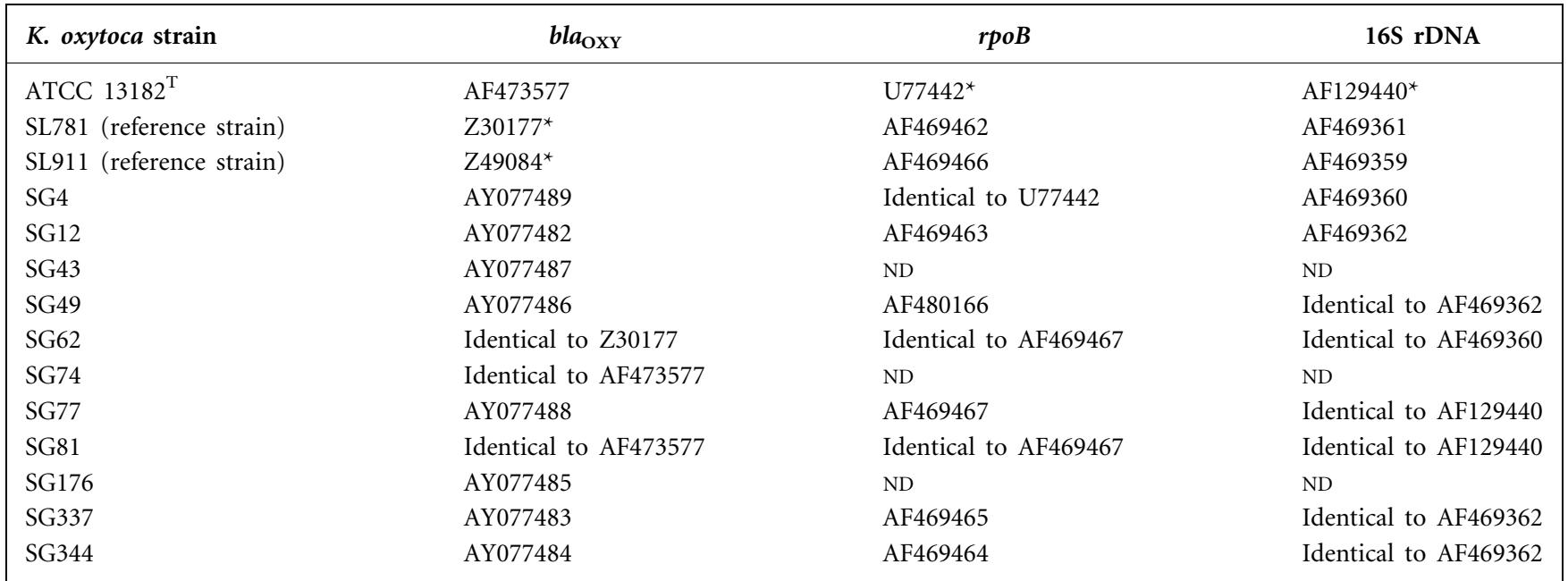

${ }^{\star}$ Previously published sequences.

ND, Not determined. 
Table 2. Nucleotide sequence of bla $\mathrm{OxY}_{-1}$ genes of Klebsiella oxytoca clinical isolates in comparison with that of reference strain SL781

\begin{tabular}{|c|c|c|c|c|c|c|c|c|c|}
\hline \multirow[t]{2}{*}{ Strain } & \multirow[t]{2}{*}{ Hospital (year) } & \multicolumn{7}{|c|}{ Nucleotide position $^{*}(\operatorname{codon} \dagger)$} & \multirow[t]{2}{*}{ Reference } \\
\hline & & -8 & $+1 \neq$ & $68-76 \$(11-13)$ & $658(208)$ & $723(230)$ & 744 (237) & $788(252)$ & \\
\hline SL781 & & G & A & GCC GCC GTT (Ala Ala Val) & $\mathrm{G}(\mathrm{Val})$ & C (Ala) & C (Ala) & G (Pro) & Fournier \& Roy (1997) \\
\hline SG12 & $1(1997)$ & A & & & & & G (Gly) & & This study \\
\hline SG49 & $2(1991)$ & A & & & A (Val) & $\mathrm{T}(\mathrm{Val})$ & G (Gly) & & This study \\
\hline SG337 & $5(1996)$ & A & & GCC---GTT (Ala Val) & & $\mathrm{T}(\mathrm{Val})$ & & & This study \\
\hline SG344 & $6(1998)$ & A & & & A (Val) & $\mathrm{T}(\mathrm{Val})$ & G (Gly) & C (Pro) & This study \\
\hline
\end{tabular}

${ }^{\star}$ Fournier et al. (1995).

$\dagger$ Ambler et al. (1991).

$¥$ Transcriptional start site.

$\$$-, Deletion.

Table 3. Nucleotide sequence of bla $\mathrm{OxY}-2$ genes of Klebsiella oxytoca clinical isolates in comparison with that of reference strain SL911

\begin{tabular}{|c|c|c|c|c|c|c|c|c|c|c|c|c|c|}
\hline \multirow[t]{2}{*}{ Strain } & \multirow[t]{2}{*}{ Hospital (year) } & \multicolumn{11}{|c|}{ Nucleotide position ${ }^{\star}(\operatorname{codon} \dagger)$} & \multirow[t]{2}{*}{ Reference } \\
\hline & & -12 & -8 & $+1 \ddagger$ & $66-74 \S(11-13)$ & $93(20)$ & $139(35)$ & $602(190)$ & $621(197)$ & $728(233)$ & 789 (255) & $804(260)$ & \\
\hline SL911 & & G & G & $\mathrm{C}$ & GCC GCC GTT (Ala Ala Val) & G (Gly) & $\mathrm{A}(\mathrm{Asp})$ & A (Leu) & G (Asp) & C (Gly) & G (Asp) & $\mathrm{G}(\mathrm{Val})$ & Fournier \& Roy (1997) \\
\hline SG43 & $2(1991)$ & $\mathrm{T}$ & & & GCC---GTT (Ala Val) & & & & & & & & This study \\
\hline SG69 & $2(1998)$ & $\mathrm{T}$ & & & GCC---GTT (Ala Val) & & & & & & & & This study \\
\hline SG77 & $3(1994)$ & & A & & GCC---GTT (Ala Val) & & & & & & & & This study \\
\hline SG9 & $1(1984)$ & & A & & GCC---GTT (Ala Val) & & & & & & & & This study \\
\hline SG74 & $1(1999)$ & & & & & & & G (Leu) & & & & A (Ile) & This study \\
\hline SG81 & $1(1999)$ & & & & & & & G (Leu) & & & & A (Ile) & $\begin{array}{l}\text { This study; Granier } \\
\text { et al. (2002b) }\end{array}$ \\
\hline SG4 & $1(1998)$ & & A & & & & & G (Leu) & A (Asn) & A (Gly) & & & This study \\
\hline SG62 & 4 (1998) & & A & & & & C (Ala) & G (Leu) & A (Asn) & & A (Asn) & & This study \\
\hline SG176 & $1(2000)$ & & & & & A (Ser) & & & & & & & This study \\
\hline
\end{tabular}

${ }^{*}$ Fournier et al. (1995).

†Ambler et al. (1991).

$\ddagger$ Transcriptional start site.

\$-, Deletion. 
the $b l a_{\mathrm{OXY}-2}$ genes harboured by our nine clinical isolates (Tables 2 and 3 ).

Table 4 shows that the mean percentage of $b l a_{\text {OXY }}$ gene identity observed within each group of bla $a_{\mathrm{OXY}}$ genes was $>99 \%$, whereas it was lower (about $87 \%$ ) between the two groups of bla $a_{\mathrm{OXY}}$ genes.

\section{$16 S$ rRNA and $r p o B$ gene sequences}

The sequence of the 16S rRNA and $r p o B$ genes was determined for five strains harbouring the $b l a_{\mathrm{OXY}-1}$ gene (the four clinical isolates and reference strain SL781) and for five strains harbouring the $b l a_{\mathrm{OXY}-2}$ gene, including four clinical isolates (SG77, SG81, SG4 and SG62) and reference strain SL911.

The sequence of the 16S rDNA fragment studied (387 bp) was identical for the five strains harbouring the $b l a_{\mathrm{OXY}-1}$ gene, except for reference strain SL781, in which a single nucleotide substitution was observed. The sequence of the corresponding $16 \mathrm{~S}$ rDNA fragment in the strains possessing the $b l a_{\mathrm{OXY}-2}$ gene was also largely conserved, but four different substitutions were observed, each in a single strain. Comparison of the $16 \mathrm{~S}$ rDNA consensus sequences of the two types of strains, available as Supplementary Fig. A in IJSEM Online, showed that the two sequences differed from each other by seven nucleotide substitutions, located close to each other in a small fragment from positions 435 to 458 according to the numbering of the E. coli $16 \mathrm{~S}$ rDNA sequence.

By using the $r p o B$ fragment (512 bp), which is relevant to the differentiation of enterobacterial species, we observed that the nucleotide sequence was identical for three of the five strains harbouring the $b l a_{\mathrm{OXY}-1}$ gene, whereas the two remaining strains differed from the three others (as well as from each other) by one substitution. The same feature was observed in the five strains possessing the $b l a_{\mathrm{OXY}-2}$ gene, leading to an identical nucleotide sequence for three strains and two different nucleotide substitutions distinguishing the two remaining strains from each other as well as from the other three strains. As indicated in Fig. B (available as supplementary data in IJSEM Online), the $r p o B$ consensus sequence of the strains with the blaxy-1 gene differed from that of the strains with the $b l a_{\mathrm{OXY}-2}$ gene by 17 nucleotide substitutions, distributed all along the 512 bp fragment.

Table 4 shows that the mean percentage of gene identity for pairs of strains was very high $(>99 \%)$ for both the $r p o B$ and $16 \mathrm{~S}$ rRNA genes within each group of strains, but lower between the two groups of strains: $<97 \%$ for the $r p o B$ gene and approximately $97 \cdot 5 \%$ for the $16 \mathrm{~S}$ rRNA gene.

\section{Phylogenetic relationships among $K$. oxytoca and other genera in the Enterobacteriaceae}

The phylogenetic trees resulting from the separate analyses of $r p o B$ and $16 \mathrm{~S}$ rDNA datasets are not shown here. Combination of the datasets globally produced a similar topology, with better robustness and resolution. The combined analysis was computed on 980 molecular characters, of which 61 were parsimony-informative. This led to three trees (length $=392$ steps, Ciex $=0 \cdot 6250$, Hiex $=$ $0 \cdot 3750)$. The ten unrelated K. oxytoca strains were monophyletic and separated into two clades, corresponding to the strains with the $b l a_{\mathrm{OXY}-1}$ gene and the strains with the $b l a_{\mathrm{OXY}-2}$ gene. This result was supported by high bootstrap values of 97 and $99 \%$, respectively. The strict consensus of the three trees is shown in Fig. 1 with the bootstrap values.

\section{Arbitrarily amplified DNA polymorphism}

As shown in Fig. 2, although the arbitrarily amplified DNA profiles of the ten unlinked strains differed from each other, we can observe two clearly distinct profile types, each related to one of the two types of strains defined by the OXY $\beta$-lactamase harboured. Thus, two intense bands of approximately 1400 and $1600 \mathrm{bp}$ are always present in strains harbouring the $b a_{\mathrm{OXY}-1}$ gene and never in the strains with the $b l a_{\mathrm{OXY}-2}$ gene; likewise, one or two intense bands of approximately $500 \mathrm{bp}$ are always present in strains possessing the $b l a_{\mathrm{OXY}-2}$ gene and never in those with the $b l a_{\mathrm{OXY}-1}$ gene.

Table 4. Mean percentage of $b / a_{\mathrm{OXY}}, r p o B$ and $16 \mathrm{~S}$ rRNA gene identity within and between the groups of strains with bla $\mathrm{OXY}-1$ and bla $\mathrm{OXY}-2$ genes

The bla $a_{\mathrm{OXY}-1}$ group includes strains SG12, SG49, SG337, SG344 and SL781; the bla $a_{\mathrm{OXY}-2}$ group includes strains SG4, SG62, SG77, SG81 and SL911.

\begin{tabular}{|lccc|}
\hline \multirow{2}{*}{ Comparison of strains } & \multicolumn{3}{c|}{ Mean percentage identity \pm SE } \\
\cline { 2 - 4 } & $\boldsymbol{b l a}_{\mathrm{OXY}}$ & $\boldsymbol{r p o B}$ & 16S rRNA \\
\hline$b l a_{\mathrm{OXY}-1}$ vs $b l a_{\mathrm{OXY}-1}$ & $99 \cdot 659 \pm 0 \cdot 202$ & $99 \cdot 646 \pm 0 \cdot 153$ & $99 \cdot 684 \pm 0 \cdot 408$ \\
$b l a_{\mathrm{OXY}-2}$ vs $b l a_{\mathrm{OXY}-2}$ & $99 \cdot 651 \pm 0 \cdot 260$ & $99 \cdot 841 \pm 0 \cdot 124$ & $99 \cdot 528 \pm 0 \cdot 408$ \\
$b l a_{\mathrm{OXY}-1}$ vs $b l a_{\mathrm{OXY}-2}$ & $86 \cdot 857 \pm 0 \cdot 403$ & $96 \cdot 562 \pm 0 \cdot 241$ & $97 \cdot 801 \pm 0 \cdot 215$ \\
\hline
\end{tabular}




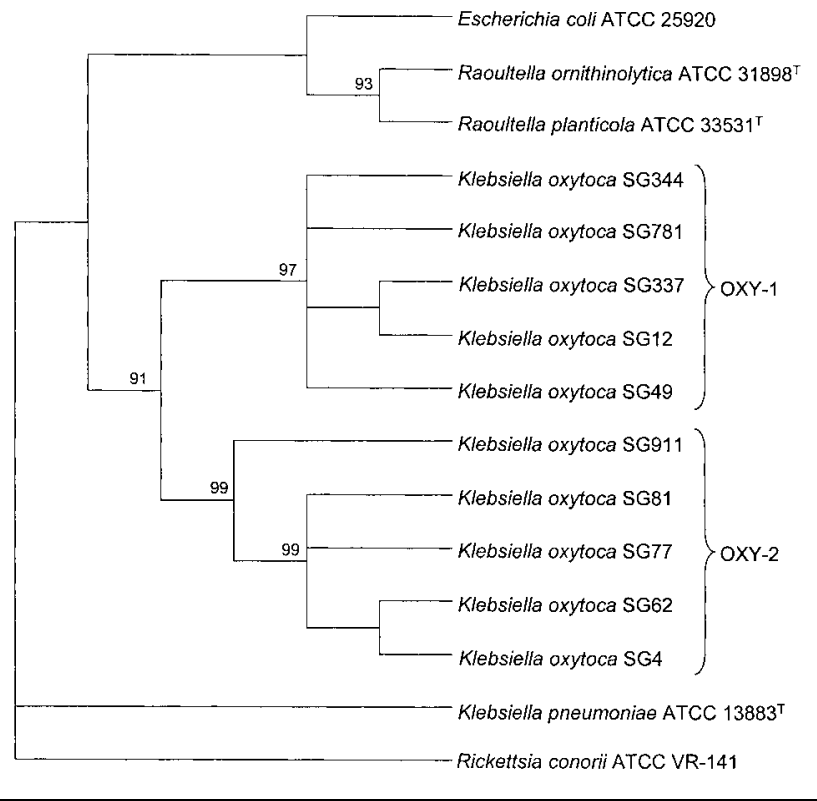

Fig. 1. Phylogenetic tree derived from combined analysis of the $16 \mathrm{~S}$ rDNA and $r p o B$ sequences of five Klebsiella oxytoca strains harbouring the bla $\mathrm{OXY}_{-1}$ gene (SG344, SL781, SG337, SG12 and SG49) and five harbouring the bla OXY-2 gene (SL911, SG81, SG77, SG62 and SG4), Escherichia coli ATCC $25922^{\top}$, Raoultella ornithinolytica ATCC $31898^{\top}$, Raoultella planticola ATCC $33531^{\top}$ and Klebsiella pneumoniae ATCC $13883^{\top}$. The tree was determined by the parsimony method with Rickettsia conorii ATCC VR- $141^{\top}$ as the outgroup. Numbers within the dendogram indicate the bootstrap values of the branching order (only values of 70 and above are shown).

\section{DISCUSSION}

\section{bla oxy promoter regions}

Ten of the thirteen clinical isolates of $K$. oxytoca had been collected over a 17-year period in six French hospitals, because of their resistance spectrum that extended to ceftriaxone, cefotaxime and aztreonam. Such an extension was previously demonstrated to be due to the overproduction of $\beta$-lactamase in relation to up-mutations (Fournier et al., 1995). Effectively, we found the two previously determined types of substitutions located in the -10 region of the promoter of the gene encoding the OXY- 1 and OXY- $2 \beta$-lactamase of the ten clinical isolates (Fournier et al., 1996a). For the three remaining strains, which were phenotypically susceptible to third-generation cephalosporins and aztreonam, no substitution was found in the promoter region.

\section{$\beta$-Lactamase diversity within the $O X Y-1$ and OXY-2 groups}

Among the OXY-1 and OXY-2 $\beta$-lactamases found in our clinical isolates, some differences were observed in the primary gene sequence of the $\beta$-lactamase in each group.

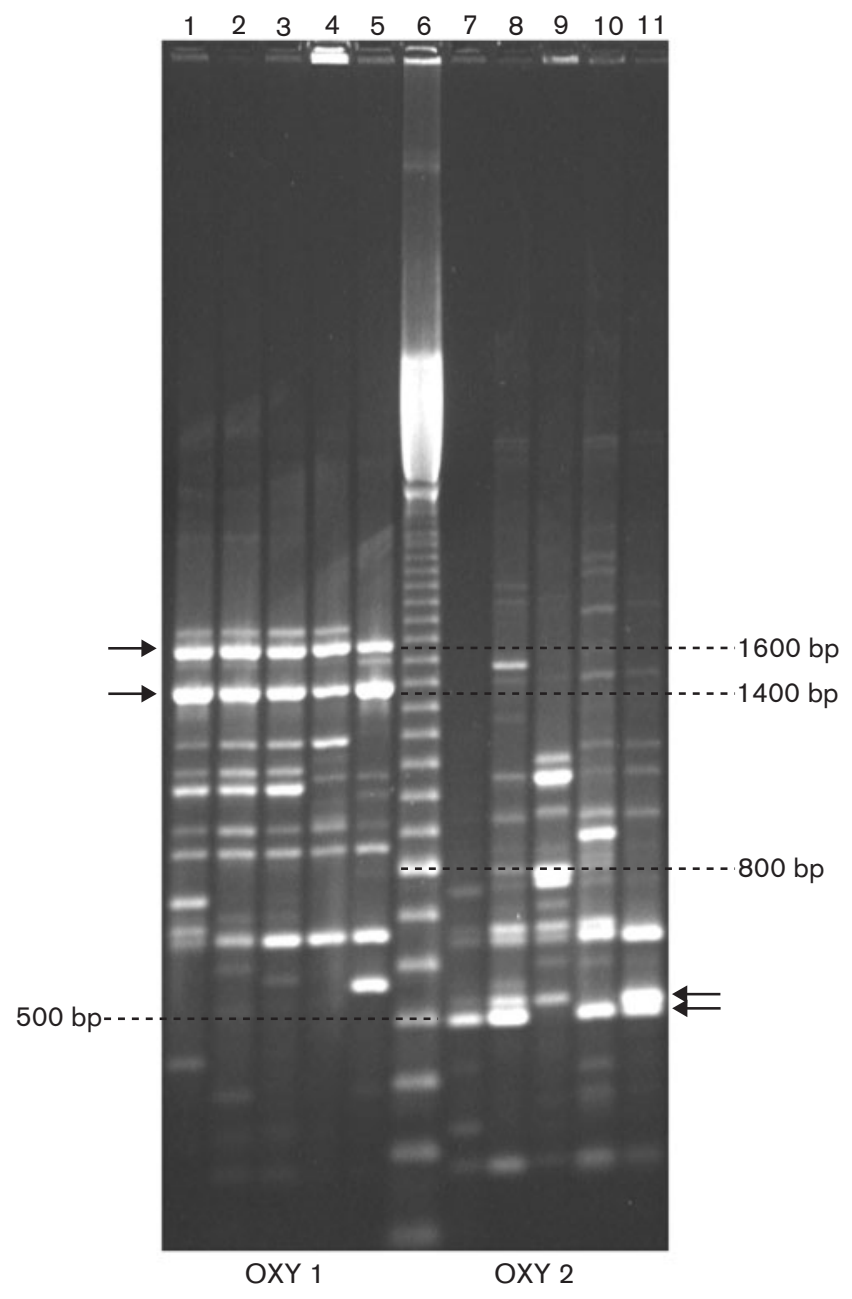

Fig. 2. Agarose gel electrophoresis of arbitrarily amplified DNA polymorphism of Klebsiella oxytoca isolates. Strains SG12, SG49, SG337, SG344 and reference strain SL781 (harbouring the bla OXY-1 gene) are presented in lanes 1-5, respectively. Strains SG4, SG62, SG77, SG81 and reference strain SL911 (harbouring the bla OXY-2 gene) are presented in lanes 7-11, respectively. Lane 6 corresponds to the molecular size marker (100 bp ladder, Amersham Biosciences) with the most intense band corresponding to $800 \mathrm{bp}$. Arrows indicate the principal fragments which allow us to distinguish the two types of K. oxytoca strains.

Regarding the $\beta$-lactamases of the OXY-1 group, the two amino acid substitutions observed in our strains, Ala237Gly and Ala230Val, have already been described and shown to have no effect on hydrolytic activity (Fournier \& Roy, 1997). However, they have never been described alone (Ala237Gly in strain SG12), nor combined with each other without other amino acid substitutions (strains SG49 and SG344), nor combined with the new genetic feature displayed by the OXY-1 $\beta$-lactamase of strain SG337. Indeed, the $b l a_{\mathrm{OXY}-1}$ gene of this strain displayed a deletion of three nucleotides leading to the deletion of the last of the four Ala residues located 12 codons downstream from the starting Met, i.e. 
located in the signal peptide. By taking into account the published protein sequences of OXY-1 $\beta$-lactamase and those presented here, eight OXY-1 $\beta$-lactamases have been molecularly characterized to date (Fournier \& Roy, 1997; Wu et al., 1999).

Concerning the OXY-2 $\beta$-lactamases, those produced by strains SG4 and SG62 corresponded to two of the four published by Fournier et al. (1997). Although they were not epidemiologically related, four of our clinical isolates had an identical OXY-2 $\beta$-lactamase, characterized by the deletion of an Ala residue belonging to the Ala-Ala-Ala motif located in the signal peptide. By consulting the literature, we found that this deletion is present in two previously published OXY- $2 \beta$-lactamases, without mention by the authors (Kimura et al., 1996; Wu et al., 1999). Another modification was found in the signal peptide sequence, namely Gly20Ser (strain SG176), which was also published previously, but was associated with other amino acid substitutions (Granier et al., 2002a; Sirot et al., 1998). Finally, strains SG74 and SG81 harboured an OXY-2 $\beta$-lactamase with a novel amino acid substitution, Val260Ile. As both strains SG74 and SG81 were susceptible to third-generation cephalosporins and aztreonam, substitution Val260Ile does not appear to modify the hydrolytic activity of the enzyme.

Overall, by considering the published OXY- $2 \beta$-lactamases and those presented here, nine OXY- $2 \beta$-lactamases have been characterized to date. Comparison of the sequence of published $b a_{\text {OXY }}$ genes with those found in our clinical isolates confirmed that the percentage of gene identity was extremely high ( $>99 \%)$ within each $b l a_{\mathrm{OXY}}$ gene group, and significantly lower, about $87 \%$, between the two bla $a_{\mathrm{OXY}}$ gene groups.

\section{Two clades in the $K$. oxytoca taxon}

By studying three chromosomal genes $\left(b l a_{\mathrm{OXY}}, 16 \mathrm{~S}\right.$ rDNA and $r p o B$ ) of ten unrelated $K$. oxytoca strains, we were able to define two clades in the $K$. oxytoca taxon. This finding is in accordance with the study of Brisse et al. (2001), which had shown, using other genes (namely gyrA and parC) and different typing methods (RAPD and ribotyping), that six clinical isolates of $K$. oxytoca and reference strain $K$. oxytoca NCTC 49131 were classified into two clusters. The new relevant point in our study is the demonstration that this genetic delineation was also obtained from the chromosomal $\beta$-lactamase gene of $K$. oxytoca, which does not belong to the housekeeping gene family. To our knowledge, it is the first demonstration of a chromosomal $\beta$-lactamase that is able to divide a taxon into clades. This finding suggests that chromosomal bla genes, which are extremely common in the Enterobacteriaceae, are affected by an evolutionary process, as well as housekeeping genes. Therefore, evolution of the bla gene might also reflect species evolution.

The second significant point of our study is that the $16 \mathrm{~S}$ rRNA gene, although it has a low evolutionary rate, was also able to define the two clades in the K. oxytoca taxon (Palys et al., 1997). Moreover, another discriminatory gene recently used in parallel with the $16 \mathrm{~S}$ rRNA gene to establish the phylogenetic relationships of enterobacterial species, namely the $r p o B$ gene, was also able to delineate the two clades (Mollet et al., 1997).

Regarding K. oxytoca strain ATCC $13182^{\mathrm{T}}$, which was used by Mollet et al. (1997) and Drancourt et al. (2001) to establish the phylogenetic relationships between enterobacterial species, we deduced from the comparison of its $16 \mathrm{~S}$ rDNA and rpoB sequences (GenBank accession numbers AF129440 and U77442, respectively) with the 16S rDNA and $r p o B$ consensus sequences from this study, that its $\beta$-lactamase belongs to the OXY- $2 \beta$-lactamase group. We confirmed this classification by sequencing the $b l a_{\mathrm{OXY}}$ gene and we found that the OXY-2 $\beta$-lactamase of this strain differs from the reference sequence (strain SL911) by the substitution Val260Ile (data not shown).

This result means that species identification and determination of the OXY $\beta$-lactamase category can be achieved by a single PCR, and sequencing of either the 16S rRNA gene or $r p o B$ gene. To state that PCR of the $b l a_{\mathrm{OXY}}$ gene can also be used to identify the species as well as the category of $\beta$-lactamase, we have to verify that the primers used are not able to amplify any other bla gene.

Considering the fact that each K. oxytoca isolate is classified into one of the two clades regardless of the gene sequence used $\left(b a_{\mathrm{OXY}}, 16 \mathrm{~S} \mathrm{rDNA}, r p o B\right)$ and that the two clades were delineated with bootstrap values as high as those that delineate the two Raoultella species studied, we suggest that K. oxytoca should be divided into two genetic groups, group oxy-1 represented by $K$. oxytoca strain SL781 (=CIP 104963) and group oxy-2 by K. oxytoca strain SL911 ( = CIP 106098).

The last point resulting from our study is the fact that the two genetic groups of $K$. oxytoca can be distinguished by using the ERIC-1R PCR method, as the isolates of these two groups display distinct profiles, each with characteristic bands. Such a procedure, if it is confirmed on a larger collection of $K$. oxytoca isolates, could be carried out in molecular epidemiological studies and in laboratories that do not yet have access to the gene amplification and sequencing methods, which are both time-consuming and expensive (Olive \& Bean, 1999).

\section{ACKNOWLEDGEMENTS}

We would like to thank Dr B. Fournier and Professor M. Drancourt for providing us with the two reference strains SL781 and SL911, and K. oxytoca ATCC $13182^{\mathrm{T}}$, respectively. We are grateful to Professor Euzéby for his helpful advice and comments. This study was supported by a grant from GlaxoWellcome and a grant from the 'Ministère de la Recherche - Ministère de l'Education Nationale' (Programme Microbiologie 1998-2002). 


\section{REFERENCES}

Ambler, R. P., Coulson, A. F. W., Frère, J. M., Ghuysen, J. M., Joris, B., Forsman, M., Levesque, R. C., Tiraby, G. \& Waley, S. G. (1991). A standard numbering scheme for the class A $\beta$-lactamases. Biochem $J$ 276, 269-270.

Benoit, R., Danquechin-Dorval, E., Loulergue, J., Bacq, Y., Olivier, J. M., Audurier, A. \& Metman, E. H. (1992). Diarrhée post-antibiotique: rôle de Klebsiella oxytoca. Gastroenterol Clin Biol 16, 860-864.

Birnboim, H. C. (1983). A rapid alkaline extraction method for the isolation of plasmid DNA. Methods Enzymol 100, 243-255.

Boyeldieu, D., Vu-Thien, H., Dollfus, C. \& 7 other authors (1999). Septicémies à Klebsiella oxytoca après transfusion de plaquettes. Pathol Biol 47, 405-407.

Brisse, S. \& Verhoef, J. (2001). Phylogenetic diversity of Klebsiella pneumoniae and Klebsiella oxytoca clinical isolates revealed by randomly amplified polymorphic DNA, gyrA and parC genes sequencing and automated ribotyping. Int J Syst Evol Microbiol 51, 915-924.

Drancourt, M., Bollet, C., Carta, A. \& Rousselier, P. (2001). Phylogenetic analyses of Klebsiella species delineate Klebsiella and Raoultella gen. nov., with description of Raoultella ornithinolytica comb. nov., Raoultella terrigena comb. nov. and Raoultella planticola comb. nov. Int J Syst Evol Microbiol 51, 925-932.

Fournier, B. \& Roy, P. H. (1997). Variability of chromosomally encoded $\beta$-lactamases from Klebsiella oxytoca. Antimicrob Agents Chemother 41, 1641-1648.

Fournier, B., Arlet, G., Lagrange, P. H. \& Philippon, A. (1994). Klebsiella oxytoca: resistance to aztreonam by overproduction of the chromosomally encoded $\beta$-lactamase. FEMS Microbiol Lett 116, 31-36.

Fournier, B., Lu, C. Y., Lagrange, P. H., Krishnamoorthy, R. \& Philippon, A. (1995). Point mutation in the Pribnow box, the molecular basis of $\beta$-lactamase overproduction in Klebsiella oxytoca. Antimicrob Agents Chemother 39, 1365-1368.

Fournier, B., Lagrange, P. H. \& Philippon, A. (1996a). $\beta$-Lactamase gene promoters of 71 clinical strains of Klebsiella oxytoca. Antimicrob Agents Chemother 40, 460-463.

Fournier, B., Roy, P. H., Lagrange, P. H. \& Philippon, A. (1996b). Chromosomal $\beta$-lactamase genes of Klebsiella oxytoca are divided into two main groups, $b l a_{\mathrm{OXY}-1}$ and $b l a_{\mathrm{OXY}-2}$. Antimicrob Agents Chemother 40, 454-459.

Granier, S. A., Leflon-Guibout, V., Nicolas-Chanoine, M.-H., Bush, K. \& Goldstein, F. W. (2002a). The extended-spectrum K1 $\beta$ lactamase from Klebsiella oxytoca SC 10,436 is a member of the bla $_{\mathrm{OXY}-2}$ family of chromosomal Klebsiella enzymes. Antimicrob Agents Chemother 46, 2056-2057.

Granier, S. A., Nguyen Van, J.-C., Kitzis, M.-D., Goldstein, F. W., Leflon-Guibout, V. \& Nicolas-Chanoine, M.-H. (2002b). First description of a TEM-30 (IRT-2)-producing Klebsiella oxytoca isolate. Antimicrob Agents Chemother 46, 1158-1159.

Högenauer, C., Hammer, H. F., Krejs, G. J. \& Reisinger, E. C. (1998). Mechanisms and management of antibiotic-associated diarrhea. Clin Infect Dis 27, 702-710.

Huang, X. (1992). A contig assembly program based on sensitive detection of fragment overlaps. Genomics 14, 18-25.
Huelsenbeck, J. P., Bull, J. J. \& Cunningham, C. W. (1996). Combining data in phylogenetic analysis. Trends Ecol Evol 11, 152-158.

Jeong, S. H., Kim, W. M., Chang, C. L. \& 8 other authors (2001). Neonatal intensive care unit outbreak caused by a strain of Klebsiella oxytoca resistant to aztreonam due to overproduction of chromosomal $\beta$-lactamase. J Hosp Infect 48, 281-288.

Jones, G., Triep, S., Koek, A. \& Dijkshoorn, L. (1999). RAPD typing of Klebsiella pneumoniae, Klebsiella oxytoca, Serratia marcescens and Pseudomonas aeruginosa isolates using standardized reagents. Clin Microbiol Infect 5, 270-276.

Kimura, K., Arakawa, Y., Ohsuka, S., Ito, H., Suzuki, K., Kurokawa, H., Kato, N. \& Ohta, M. (1996). Molecular aspects of high-level resistance to sulbactam-cefoperazone in Klebsiella oxytoca clinical isolates. Antimicrob Agents Chemother 40, 1988-1994.

Mollet, C., Drancourt, M. \& Raoult, D. (1997). $r p o B$ sequence analysis as a novel basis for bacterial identification. Mol Microbiol 26, 1005-1011.

Monnet, D., Freney, J., Brun, Y., Boeufgras, J. M. \& Fleurette, J. (1991). Difficulties in identifying Klebsiella strains of clinical origin. Zentbl Bakteriol 274, 456-464.

Morgenstern, B. (1999). DIALIGN 2: improvement of the segment-tosegment approach to multiple sequence alignment. Bioinformatics 15, 211-218.

Olive, D. M. \& Bean, P. (1999). Principles and applications of methods for DNA-based typing of microbial organisms. J Clin Microbiol 37, 1661-1669.

Palys, T., Nakamura, L. K. \& Cohan, F. M. (1997). Discovery and classification of ecological diversity in the bacterial world: the role of DNA sequence data. Int J Syst Bacteriol 47, 1145-1156.

Reiss, I., Borkhardt, A., Füssle, R., Sziegoleit, A. \& Gortner, L. (2000). Disinfectant contaminated with Klebsiella oxytoca as a source of sepsis in babies. Lancet 356, 310.

Sirot, D., Labia, R., Pouedras, P., Chanal-Claris, C., Cerceau, C. \& Sirot, J. (1998). Inhibitor-resistant OXY-2-derived $\beta$-lactamase produced by Klebsiella oxytoca. Antimicrob Agents Chemother 42, 2184-2187.

Stock, I. \& Wiedemann, B. (2001). Natural antibiotic susceptibility of Klebsiella pneumoniae, K. oxytoca, K. planticola, K. ornithinolytica and K. terrigena strains. J Med Microbiol 50, 396-406.

Swofford, D. L. (1998). PAUP*, Phylogenetic Analysis Using Parsimony (*and other methods), version 4.b5. Champaign: Illinois Natural History Survey.

Tatusova, T. A. \& Madden, T. L. (1999). BLAST 2 Sequences, a new tool for comparing protein and nucleotide sequences. FEMS Microbiol Lett 174, 247-250.

Terrier, F., Algayres, J. P., Le Romancer, J. M., Gerome, P., Bili, H. \& Daly, J. P. (1995). Diarrhée aiguë hémorragique à Klebsiella oxytoca: association à la prise de virginamycine? Presse Med 24, 1446.

Wu, S. W., Dornbusch, K. \& Kronvall, G. (1999). Genetic chracterization of resistance to extended-spectrum $\beta$-lactams in Klebsiella oxytoca isolates recovered from patients with septicemia at hospitals in the Stockholm area. Antimicrob Agents Chemother 43, 1294-1297. 